\title{
The Judicialization of the Municipal Electoral Competition in Brazil: A Study on Supplementary Elections from 2004 to 2018
}

\author{
Ary Jorge Nogueira \\ Federal University of the State of Rio de Janeiro, UNIRIO, Rio de Janeiro, Brazil \\ Email: aryjorge.nogueira@hotmail.com
}

How to cite this paper: Nogueira, A. J. (2019). The Judicialization of the Municipal Electoral Competition in Brazil: A Study on Supplementary Elections from 2004 to 2018. Beijing Law Review, 10, 1282-1304. https://doi.org/10.4236/blr.2019.105069

Received: November 15, 2019

Accepted: December 9, 2019

Published: December 12, 2019

Copyright $\odot 2019$ by author(s) and Scientific Research Publishing Inc. This work is licensed under the Creative Commons Attribution International License (CC BY 4.0).

http://creativecommons.org/licenses/by/4.0/

\begin{abstract}
This study has the main objective of verifying the presupposition of Marchetti (2013) that the recent electoral competition that is marked by the judicialization also applies to the scope of the supplementary elections. The main hypothesis of the work is that the judicialization of municipal electoral competition has become an additional strategy used by political actors because of its effectiveness. The results indicate that approximately $58 \%$ of the Supplementary Elections that occurred in the period were motivated solely by lawsuits filed by opposition political groups. In these cases, the opposition can elect the new mayors in $62 \%$ of situations.
\end{abstract}

\section{Keywords}

Judicialization, Electoral Competition, Supplementary Elections

\section{Introduction}

Every four years, Brazil holds thousands of municipal elections that usually go without major problems. However, in many municipalities, the situation does not remain stable, and after a certain time, new elections, known as supplementary elections, are being convened. On these occasions, voters return to the polls to choose the mayor again ${ }^{1}$.

Usually these elections are preceded by a real judicial war, fought between opposing groups and/or Public Prosecution and the elected candidates. In this context, the role of the electoral judiciary is evident, because it is up to it to define whether the result of the polls will prevail, or whether citizens will be called

${ }^{1}$ There was never an additional election for President of the Republic and only two supplementary elections occurred for the Governor of State (Amazonas, 2017, Tocantins, 2018). 
to hold a new election.

This judicialization of the municipal electoral competition that culminates in the deposition and consequent call of new elections is the subject of this paper. The 433 municipal supplementary elections that took place in Brazil from November 2004 to October 2018, related to the regular elections of 2004, 2008, 2012 and 2016 , were analyzed. The sample is intended to map more than $80 \%$ of all the supplementary elections already held in Brazil.

The main objective of this paper is to verify whether Marchetti's (2013) assumption that recent electoral competition is marked by judicialization also applies to the scope of supplementary elections. In other words, the paper attempts to measure the impact of what was conventionally called the "judicialization of politics" (Tate, 1995) in the phenomenon of Brazilian municipal supplementary elections. The hypothesis of the work is that the judicialization of municipal electoral competition has become an additional campaign strategy used by political actors because of its effectiveness.

The role of the judiciary has been called by some, the "judicialization of politics" (Vallinder, 1995) and by others, "judicial activism" (Kmiec, 2004). Although the concept of the "judicialization of politics" is subject to criticism, (Hamlin, Kawar, \& Sala, 2015), even authors who discard their validity as an interpretative category in the literature, we understand that the term fulfills a relevant descriptive role regarding the activism exercised by the Judiciary in the democracies in the last two decades (Koerner, Inatomi, \& Baratto, 2011).

The article is divided into five sections, in addition to the introduction and conclusion. In the first section, the work methodology is presented. The following sections present the studies on the judicialization of politics, as well as the judicialization of electoral competition in Brazil. The fourth section defines supplementary election and the fifth presents the empirical results of the research.

\section{Methodology}

\subsection{Data Collection}

The dataset used was constructed from four different sources. The first is the Superior Electoral Court (TSE) data repository, which contains information about the results of the elections in Brazil, especially those elected in regular and supplementary elections, their respective votes and the total number of voters able to vote in those elections. The second data source, also managed by the TSE, is the system for the dissemination of candidacies and accountability (DivulgaCandContas), from which data can be obtained on the party coalitions that competed in the regular and supplementary elections.

Finally, data on the population estimated for the municipalities studied were obtained from the Brazilian Institute of Geography and Statistics (IBGE). The information on the reasons that determined the new elections in each municipality, as well as the respective legal grounds, was obtained in the systems of the Regional Electoral Courts of the States (TRE's). 
All the data has gone through at least one double check, since the Electoral Justice databases are not yet fully reliable. In addition to the TSE check, the data were checked against the respective Regional Courts and with newspaper reports available on the World Wide Web.

Such a measure was necessary because the repository of electoral data, which was to be the main source of information, was not complete. As an example, the supplementary elections held in the State of São Paulo in 2004 are not available in that database. Likewise, the supplementary election calendar on the TSE website only lists data until the year 2007.

\subsection{Research Design}

Data were compiled in 23 descriptive categories: year of regular election; date of the deposition decision; date of the supplementary election; Federation unity; County; number of inhabitants; previous mayor; party of the former mayor; deposed mayor; party and coalition of the deposed mayor; number of votes in the regular election; percentage of valid votes of the deposed in the regular election; political alignment of the deposed mayor in the municipality (ally or opposition); the position of the deposed mayor in relation to the term of office (re-election or new term of office); mayor elected in the supplementary election; party and coalition of the mayor elected in the supplementary election; number of votes of the elect in the supplementary election; political alignment of the elected mayor in the supplementary election in relation to the deposed (ally or opposition); reason for the additional election; legal basis and origin of the decision (if the decision of cassation of a plaque or refusal of registration was pronounced by the electoral judge or by the respective court).

The composition of his party coalition was used as a criterion to position a candidate as being opposed to the previous government. If the former mayor's party was part of the coalition of the next mayor, he was treated as an ally candidate. Otherwise, it was considered as opposing. This same criterion was adopted in the alignment of the authorship of the deposition actions. If they were tried by a party or coalition of which the defendant was not part, they remained classified as opposing.

The reasons for the deposition deserve clarification. Ineligibility was divided into two distinct moments: whether it occurred before Complementary Law 135/10 (Clean Registry Act), or whether it occurred after that law was instituted. This measure aimed to evaluate the impact of the new legislation on the phenomenon of the judicialization of politics, since the legal regime of ineligibilities changed greatly.

Kinzo's criterion $(2004,2007)$ was used to establish the ideological position of the parties (left, center and right), with adaptations to accommodate the recent party expansion that led to 35-the number of parties in Brazil with access to the Special Fund Campaign Financing Plan, FEFC for the 2018 Elections.

When the party was only the result of a name change or the split of another 
party, the ideological alignment of the original party was considered. When the party was effectively a new political actor, its most common alliances and possible positions on substantive issues were considered (Kinzo, 2007: p. 153).

As the origin of the decision, three possibilities were established: first, second or third instance. In this way, if the decision of rejection or cassation proceeded from the electoral judge, the first instance will be considered as the origin and so on, until the TSE, understood in this work as the third electoral body. The importance of this descriptive category stems from the need to assess how much the Courts influence the local electoral dynamics and what the role of the singular judges in this process is.

Regarding the date of the decision to cancel the plaque or the rejection of the candidature registration, the date of the first decision pronounced by a collegiate body (TRE or TSE) was chosen, either by confirming the first-degree judgment that had already determined the rejection of the registration or the plaque, or by reforming the decision that had allowed the subsequently deposed candidate to compete.

Thus, the date considered will always be that of the decision rendered by a collegiate body that gave rise to a new election. It is justified to adopt this criterion because the collegiate decision became the starting point for the determination of ineligibility based on the Clean Registry Act. In practice, it means to say that the decision that effectively "has validity" is that which is pronounced by a collegiate body.

The research then mapped 433 supplementary elections pertaining to the municipal elections of 2004, 2008, 2012 and 2016, all of which had occurred in 411 cities. The discrepancy between the numbers is due to the occurrence of more than one supplementary election in the same municipality. The oldest supplementary election took place in November 2004, and the cutoff date was set on October 28, 2018, the same time on which the second round of the Presidential Elections was held.

Upon consulting with the TSE and the TRE's of all states who managed to find the register of previous elections prior to 2004 in only three states. In Rio de Janeiro, the election occurred in Italva, in 1984 and in São Paulo, the elections occurred in Guaíra (2003), Guaiçara (2002), Araçoiaba da Serra (2002) and Balbinos (2002). In the State of Minas Gerais there are 22 extemporaneous elections of mayors that occurred between 1963 and 2000. However, supplementary elections, as we know them, were created only with the Electoral Code of 1965. Therefore, it is observed that the sample contains almost the entire gamut of the phenomenon that one intends to study.

\section{Judicialization of Politics Studies in Brazil}

This section intends to present a brief history about the phenomenon of the judicialization of politics in Brazil. The first academic papers dealing with the judicialization of politics in Brazil were the dissertations of Marcus Faro de Castro 
(1993) and Ariosto Teixeira (1997). While the former studied the Direct Unconstitutionality Actions (Adins) of the political parties between October 1988 and February 1993, comparing them with those initiated by the Brazilian Bar Association $(\mathrm{OAB})$ and the trade union confederations, the latter directed its research to the Adins proposed by the political parties, trade union confederations or national class entities and $\mathrm{OAB}$, extending the period covered until 1996.

The two main conclusions pointed out by Castro (1993) are in line with what international literature has always pointed out in relation to the phenomenon of the judicialization of politics. The first conclusion is that political parties have transferred to the court an important part of the politics, utilizing the Adins as instruments for questioning the government's economic policy and aiming for a more aggressive politics from the distributive point of view (CASTRO, 1993, pp. 51-52). The second conclusion points out that there would be an institutional vacuum capable of being filled by the innovation of constitutional rules (Castro, 1993: p. 53).

For Teixeira (1997), the judicialization of politics occurs when one of the following hypotheses is verified, or both: 1) "courts or judges make or extend their participation in the decision-making process regarding the formulation and/or implementation of public policies"; or 2) "non-judicial negotiations and typically political decision-making forums are affected or begin to adopt rules and procedures in their operation and in the behavior of their operators."

The later work of Vianna et al. (1999), sought to analyze all the 1935 Adins filed by the end of 1998 year, observing in each one the year of distribution, the applicants, the requirements, the legal provisions questioned, the constitutional justification, the judgment regarding injunctions and the merits of the action. The authors emphasized (Vianna et al., 1999: p. 10) that the artificial imposition of a free market in Brazil from 1989 onwards led to a process in which parliamentary majorities imposed a new vision that ended up recovering the most anachronistic things in Brazilian politics.

Nor would the judiciary have been unscathed by the process of establishing a decision-making process (Vianna et al., 1999: pp. 11-12), with proposals that have a binding effect on the decisions handed down at its summit, which ended up putting autonomy of the magistrates of the first degree.

The main works on the judicialization of politics usually focus on the role played by the Courts, especially the Federal Supreme Court (STF) and the TSE, in the clashes with the other powers (Arantes, 2005; Arantes \& Kerche, 1999; Carvalho, 2004; Marchetti, 2004, 2008, 2013; Marchetti \& Cortez, 2015; Oliveira, 2005; Pogrebinschi, 2012; Taylor, 2006, 2007).

The focus of research in the Adins is not the only one, nor is it the best way to study the phenomenon of the expansion of the judiciary (Silva, 2004: p. 134). It is true that the 1988 Constitution was the great catalyst for the phenomenon in Brazil (Ribeiro, 2001: p. 55) and affected the country's judiciary. 
For Barboza and Kozicki (2012), the judicialization of politics can be studied in several aspects, and it can be said that the very idea of constitutionalism, as well as the prediction of political issues in the Constitution, would allow the judiciary to face any political issue as a constitutional issue. The authors also point out that, although it is apparently against the interests of the Parliament, it can be said that there is a consensus that the acceptance of new roles by the judiciary is being accepted by society itself, since the actors themselves would see the judiciary as an appropriate forum to address these issues.

Verbicaro (2008) points out that there is a strong connection between the flowering of democracy and the expansion of judicialization, and in present-day Brazil there are several conditions conducive to this process, among which the following can be highlighted: the existence of a Constitutional Charter with open texture, program norms and indeterminate clauses; the expansion of the space reserved for the STF; the permission by the 1988 Constitution for the Executive to issue provisional measures; the expansion of the role of the legitimized assets to propose the direct action of unconstitutionality; the rapid modification of Brazil's economic base; the existence of new social forces represented by important movements, organizations and social groups; legislative hypertrophy; the disproportionality of political representation and the growing inefficiency of the political decision-making system.

Finally, it should be pointed out that there are authors who differentiate between judicial activism and judicialization of politics (Tassinari, 2013; Streck, 2017: p. 87), which is understood as a sort of corruption in the relationship between the Powers, inasmuch as there would be an extrapolation of the limits on the judiciary's action through a decision that is taken from non-legal criteria. In this work, we chose to treat judicial activism and judicialization of politics as similar terms, especially since most authors understand them.

In the following section, we will see how a byproduct of the judicialization of politics, the judicialization of electoral competition, has been treated in the Brazilian literature.

\section{Judicialization of Electoral Competition in Brazil}

This section intends to discuss the judicialization of electoral competition in Brazil, from the main national authors. Like Marchetti (2013) and Zalamena (2013), we adopt the assumption that the recent political-partisan competition is marked by the judicialization. And we do it for basically two reasons: the structure of electoral governance in Brazil, which is extremely judicialized, and the positions of the High Courts on eminently electoral issues.

The concept of electoral governance gained academic prominence from Huntington's work (1994), which points to the emergence of concern about the credibility of electoral results in democracies born in the third democratic wave. The concern of these new regimes would be to ensure that poll results are fair, transparent and accepted by political competitors. 
For Mozaffar and Schedler (2002), electoral governance would be a comprehensive number of activities that create and maintain the vast institutional framework in which voting and electoral competition take place. It operates on three different levels: rulemaking, rule-application, and adjudication. These three functions would not be attributions of one organ only. According to the authors, the first function would be at the legislative level, the second at the administrative level and the third at the judicial level.

The Electoral Justice of Brazil is a product of the Revolution of 1930 and was inspired by the flags raised at the time: criticism of the competitive oligarchy that had settled along the first republic and the evident discredit of the electoral process, marked by coronelismo ${ }^{2}$ (Marchetti, 2013: p. 41). In the Brazilian case, the electoral body is made up of the TSE, the TRE's of the States, the electoral judges and the electoral boards. The first is the umbrella body of the Electoral Justice and is composed of at least seven members who are elected by secret ballot: three judges from the STF ministers and two judges from the ministers of the Superior Court of Justice (STJ). Two other judges are chosen by the President of the Republic in a six-fold list of lawyers elaborated by the STF (article 119, Federal Constitution).

The Constitution of the Republic also determines the composition of the 27 TRE's in its Article 120. The TRE's are composed of seven members chosen as follows: by secret ballot, two judges from the judges of the State Court of Justice (TJ) and two judges from among judges chosen by the respective Court of Justice; one judge of the Federal Regional Court and two judges appointed by the President of the Republic, chosen from a list of sixty lawyers appointed by the Court of Justice.

The electoral judges, according to Article 118, III, of the Federal Constitution are judges of law selected by the respective Regional Court. Its jurisdiction is the electoral zone, a geographical circumscription that may coincide with one or more municipalities. The Electoral Boards, finally, are temporary organs and serve only for the execution of the electoral process. Article 121 of the Federal Constitution establishes that they are composed of two or four citizens with notorious suitability, appointed by the Electoral Judge and appointed by the President of the TRE. The boards help the electoral judge perform the necessary procedures for the electoral process in each area.

As the juridical legal theory emphasizes (Gomes, 2017; Ribeiro, 1990), electoral justice exercises administrative, jurisdictional, normative and consultative functions. In other words, it is not only responsible for organizing elections (the application of rules) and for judging electoral disputes (adjudication of rules), but also for formulating resolutions of a clearly normative nature (rulemaking), as well as providing information on concrete issues to legally legitimize inter-

${ }^{2}$ Coronelismo is a Brazilianism used to define the complex power structure that begins at the municipal level, exercised with private hypertrophy, the figure of the coronel - on the public power - the State, and having as secondary characters the electoral fraud and disorganization of public services and encompassed the entire political system of the country during the Brazilian Old Republic. 
ested parties. Thus, the way the Brazilian electoral body is structured by itself favors the judicialization of any electoral issues. After all, the executive body of the country's electoral body is made up of judges who accumulate administrative functions.

As already anticipated, the second reason we adopted the assumption of the judicialization of political-partisan competition would be the decisions of the TSE and the STF that impacted the rules of competitive play compiled by Marchetti's (2013) work: the decision on the verticalization of party coalitions; the decision that reduced the number of city councilors in Brazil; the unconstitutionality of the barrier clause and the division of the party fund; and the decision on party loyalty. Zauli (2011) adds to the list the TSE's decision on the validity of Complementary Law 135/10 (Clean Registry Act) for the 2010 elections.

The first decision of the Superior Court was given in 2002 in response to a query formulated by then Federal Deputy Miro Teixeira (PDT). The Court held that the principle by which parties are organized prevented alliances in the States from countering national coalitions (for the office of President of the Republic). The decision caused many repercussions in the political world and provoked a legislative reaction, with the approval on February 08, 2006 by the Chamber of a Constitutional Amendment (PEC 548/02), determining the end of the rule of verticalization, which was only valid for the elections, in accordance with the principals of annual electoral laws ${ }^{3}$.

The second decision was issued by the STF in an extraordinary appeal filed by the Public Prosecutor's office of the State of São Paulo in which it was intended to declare unconstitutional a change in the Organic Law of the Municipality of Mira Estrela, São Paulo, which extended the number of city councilors from that city from nine to eleven. The trial was completed only in March 2004 and the main outcome was the cancellation of 8475 councilors' vacancies across the country in the 2004 elections.

The next decision was also made by the STF Plenary, which declared that the provisions of Law 9096/95 (Law of Political Parties) that instituted the so-called "barrier clause" were unconstitutional. The unanimous decision was taken in the joint trial of two direct actions of unconstitutionality (Adins 1351 and 1354), filed by the Communist Party of Brazil (PCdoB) and the Christian Socialist Party (PSC), respectively. Although the so-called barrier clause or "performance" clause did not mean the cancellation of partisan registration of parties that did not reach it, there was a direct impact on both parliamentary functioning and access to party fund resources, which in practice meant a direct threat to the political existence of small parties.

The declaration of unconstitutionality of the barrier clause had a direct im-

${ }^{3}$ The principals of annual electoral laws (also called electoral precedence) was incorporated into the Constitution in 1993, with the approval of Constitutional Amendment (EC) 4, which reworded Article 16 of the Constitution: "The law that changes the electoral process will in force on the date of its publication, and does not apply to the election that occurs up to one year from the date of its validity." 
pact on the distribution of funds from the party fund, and the TSE established the new division criteria in February 2007, through Resolution 22,506. Marchetti (2013: p. 154) points out that the TSE acted very creatively in the case, establishing criteria for dividing resources without any legal basis, determining that a significant portion of the fund would be distributed equally among all parties.

Regarding the ownership of the elective mandates and party loyalty, the TSE, on March 27, 2007, answering the query formulated by the then Liberal Front Party (now Democrats), by six votes to one, issued Resolution 22,526, which decided that the parliamentary seats obtained by the proportional system (city councilors, State, District and Federal Deputies) belonged to the political parties or coalitions and not to the elected candidates.

A few months later, the TSE Plenary decided, through Resolution 22.563, of August 1, 2007, that the exchange of party, although to another of the same coalition, would imply the loss of the parliamentary mandate. Resolution $22,610 / 2007$, on the other hand, established four hypotheses considered as just cause for party partisanship without the consequent loss of office: incorporation or merger of the party; creation of a new party; substantial change or repeated deviation from the party program; and serious personal discrimination ${ }^{4}$. Also, in October 2007, the STF ratified the TSE Resolutions.

Zauli (2011) places another case of judicial activism as an example of the judicialization of national political competition: the recognition of the validity of Complementary Law 135/2010, the Clean Registry Act. On May 18, 2010, Senator Arthur Virgílio (PSDB) was registered with the TSE Consultation 1120-26.2010.6.00.0000, which asked the Tribunal: "An electoral law that provides for ineligibility and that has its entry into force before the July 5th deadline, can it effectively be applied for the 2010 general election?" The fundamental question was whether a Complementary Law on ineligibilities published in the Official Gazette on June 7, 2010 would violate the principals of annual electoral laws.

Initially, the TSE decided the applicability of the law to the General Elections of 2010, by six votes to one. Nevertheless, several candidates sought with the STF to apply claiming that the law would be unconstitutional or that it could not count for that year, by virtue of the principals of annual electoral laws.

After a troubled trial, in which there were five opposing votes and five in favor of unconstitutionality, Cezar Peluso, then president of the STF, opted to suspend the trial without proclamation of the result in September 2010. Then, on March 23,2011 , the validity of the law for the 2010 elections was overturned by six votes to five in the STF, with the decisive vote of the Minister Luiz Fux, who had

${ }^{4}$ The 2015 electoral mini-ballot (Law 13.165/2015) introduced article 22-A in the Law on Political Parties and reduced to three cases of just cause for partisan disaffiliation: substantial change or repeated deviation from the party program; severe personal political discrimination; and a change of party made during the 30-day period preceding the membership period required by law (six months) to run for the majority or proportional election at the end of the current term of office. 
arrived at the court only a month earlier. In this way, the Clean Registry Act became valid only in the 2012 elections.

According to Paranhos et al. (2014), the studies on electoral judicialization in Brazil are quite small and do not have a comprehensive research agenda. The mentioned authors affirm that in the period between 1996 and 2013 only ten articles published in Brazil referred directly to elections, that is, those that dealt with the judicialization of the electoral system and some other subareas.

Steibel (2007) deals with the right of reply, and the concept of electoral governance is explored by Marchetti (2008) and Bitencourt (2013). The focus of Shirado's work $(2008,2009)$ is partisan infidelity and ethics of legality in the application process. Ethics is also the focus of Canela's work (2012).

The research performed by Marchetti and Cortez (2009) suggests that TSE's judicial activism would indicate dissatisfaction with the rules of functioning of political competition in Brazil, and Pozzobon's (2009) study concludes that the Brazilian judiciary (post-democratization) has acted proactively. Zauli (2011) concludes that the mechanism of consultation with the electoral courts has allowed the advancement of electoral judicialization and is concerned with constitutional ethical issues.

Finally, the work of Costa (2013) analyzes the normative acts of the Electoral Justice and the interpretation of the electoral laws, (or more properly, of the Constitution). Their conclusions indicate that the Electoral Justice, through normative acts, has been changing the standards of political competition in the country.

The doctoral thesis of Nunes Junior (2014) analyzes the judicialization of politics in Brazil, also based on the decisions of the TSE and the STF on party and electoral issues, specifically the verticalization of coalitions and party loyalty. The author criticizes the fact that the interventions of the courts in the political-electoral area do not come as a result of a wide debate with the society, but rather, from the previous exposure of the alternatives considered to the criticisms of the interested social segments.

Lima and Beçak (2016), in a case study on the consultation 1398 formulated with the TSE, discuss the judicialization of mega politics from the Electoral Justice, concluding that democratic strengthening of judicial institutions is necessary.

Oliveira et al. (2018) assesses the implications of Electoral Justice activism in political-party competition. The main hypothesis is that the judicial activism of the TSE has been used as an instrument of horizontal accountability by the Judiciary, that is, control of the electoral and legislative actions of the Executive and Legislative Branches, in an atypical way, through the creation of new law in addition to its constitutional competence to regulate electoral matters.

This section deals with the Brazilian discussion on judicialization of electoral competition. The next section will present the concept of supplementary elections. 


\section{Supplementary Elections}

The concept of supplementary elections is drawn from Article 224 of the Electoral Code, which provides for the holding of new elections in basically two hypotheses: the first, when there is a nullity of votes that reaches more than half of the vote for the majority positions of President of the Republic, Governor or Mayor.

The second case of additional election occurs when the decision of the Electoral Court is to decide whether to reject the registration, the annulment of the diploma, or the loss of the mandate of the candidate elected in majority, regardless of the number of votes annulled. Initially not foreseen in the original wording of Article 224 of the Electoral Code, this hypothesis was included by Law $13,165 / 2015$, which added the third and fourth paragraphs to that article.

Thus, supplementary elections occur whenever the previous election is nullified, either by the annulment of more than half the votes, or by the removal of the elected plaque (by denial of registration, annulment of the diploma or loss of office) in the regular election.

The device had its constitutionality questioned by the Attorney General's office through ADIN 5525. The trial was finalized on March 8, 2018 and the Court, by a majority of votes, understood that the Federal legislature has the authority to institute hypotheses of new elections in case of vacancy due to the extinction of the mandate of majority positions by electoral causes, but cannot predict the form of election for president or vice president of the Republic and senators, other than that provided for in the Federal Constitution.

In addition, the ministers, by a majority, declared the expression "after the res judicata" unconstitutional, provided for in paragraph 3 of article 224 of the Electoral Code, and conferred interpretation according to the Constitution to paragraph 4 of the same article in order to depart from the incidence situations of vacancy in the positions of president and vice president of the Republic and of senator.

Supplementary elections are still a subject of little explored research in the Brazilian literature. Bibliographical research with the thesis and dissertations bank of Coordination for the Improvement of Higher Education Personnel (CAPES) detected the existence of only five dissertations (Zalamena, 2013; Coelho, 2014; Garcia, 2016; Crespo, 2017; Moura, 2018) And An Article (Crespo \& Peixoto, 2018).

The work of Zalamena (2013) analyzes the judicialization of local political competition in the municipal elections of Rio Grande do Sul, in 2008, and carried out a case study on the supplementary elections that occurred during that period. The research concludes that the local political competition has been significantly altered by the intervention of the Electoral Justice in its majoritarian lawsuits (Zalamena, 2013: p. 123).

Other research that focused on the 2008 elections, however, related to the State of Piauí, was conducted by Coelho (2014). According to the author, the ju- 
dicialization of the electoral process has bureaucratized political competition and displaced the central axis of the democratic process, since political actors note that they can obtain electoral gains through legal mechanisms (Coelho, 2014: p. 141).

Garcia (2016) seeks to relate electoral and party behavior to the socioeconomic profile of the Brazilian municipalities that held additional mayoral elections between 2013 and 2015. The author points out that the new elections modify the political groups that control power (Garcia, 2016: p. 155).

Crespo's work (2017) also addresses the supplementary elections that took place in the country but related to the regular elections of 2012. The work suggests that those who most propose actions and electoral investigations are the losers who are harmed by irregularities in ordinary elections (Crespo, 2017: p. 112).

Moura (2018) is dedicated to the use of digital social networks during the supplementary elections of the government of the State of Amazonas, not addressing the issue of municipal supplementary elections.

Finally, Crespo and Peixoto's (2018) research is devoted to the country's supplementary elections in relation to regular 2012 elections. The authors affirm that in the supplementary elections, the voters' preference would be for the choice of candidates who had already been tried and received well, to the detriment of candidates who had not participated in the annulled suit (Crespo \& Peixoto, 2018: p. 184).

This literature, however, presents limitations that need to be highlighted. Some works were restricted to a State of the Federation and to a specific year (Zalamena, 2013; Coelho, 2014), while others, although they analyzed elections that occurred throughout the country, also restricted the period studied (Garcia, 2016; Crespo \& Peixoto, 2018).

The main proposal of this work, besides filling some of the existing gaps, is to reverse the logic of the study of the judicialization of electoral competition and present the role of the first instance of the Electoral Judiciary in this process. Therefore, we assume that supplementary elections are an expression of the judicialization of politics (Zalamena, 2013).

\section{Judicialization of the Municipal Electoral Competition}

In this section the result of the research undertaken is presented. As mentioned earlier, 433 municipal elections were held in Brazil between November 2004 and October 2018, of which only six were not motivated by lawsuits ${ }^{5}$. Table 1 below shows the frequency of the supplementary elections held as a basis in the years of the invalidated elections.

Regarding the time taken to determine the mayors' deposition, on average, the

${ }^{5}$ In the cities of Jumirim and Vargem, referring to the regular elections of 2012 and in Alpestre (RS) in the 2016 elections, the municipal elections were annulled by a decision of the Municipal Legislative (Article 4, VII, Decree 201/67). In the city of Virgínia/MG (2008), there were vacancies in the positions. In Dourados/MS (2008) and Pocrane/MG (2016) the elected (and the vice) died. 
judiciary took 255 days to judge the issue. Of note are the elections whose decisions occupy the extremes of time. First, Cananéia, in the State of São Paulo in 2012, whose cancellation of the plaque happened 66 days before the elections of October 7, 2012. By virtue of preliminary injunctions, the revoked candidate continued to compete. At the other end is Coronel José Dias, in Piauí in 2008, whose decision came 1157 days after the elections of October 5, 2008.

Table 2 below shows the frequency of reasons for the occurrence of new elections. In it, it is possible to observe 11 different legal grounds for the annulment of the regular elections and the consequent deposition of the elected mayors.

As can be seen, the illicit capture of suffrage, popularly known as "vote buying," is the main reason for the occurrence of new elections (31.4\%), closely followed by the ineligibility of the Clean Registry Act (24.5\%). However, when all the modalities of ineligibilities (before and after the Clean Registry Act) are added, they occupy the first position, with a little more than $34 \%$ of the cases.

Table 1. Frequency of the supplementary elections per year of the Regular Election invalidated.

\begin{tabular}{ccc}
\hline Year (regular election) & Frequency & Percentage \\
\hline 2004 & 65 & 15.0 \\
2008 & 149 & 34.4 \\
2012 & 113 & 26.1 \\
2016 & 106 & 24.5 \\
Total & 433 & 100.0 \\
\hline
\end{tabular}

Source: Own elaboration (2018).

Table 2. Reasons for supplementary elections.

\begin{tabular}{ccc}
\hline Reasons & Frequency & Percentage \\
\hline Vote buying & 136 & 31.4 \\
Clean Registry Act & 106 & 24.5 \\
Sealed ducts & 53 & 12.2 \\
Ineligibilities & 47 & 10.9 \\
Power Abuse & 32 & 7.4 \\
Slush Funds & 17 & 3.9 \\
Professional Mayor & 15 & 3.5 \\
Formal irregularity & 14 & 3.2 \\
Nepotism & 7 & 1.6 \\
Impeachment & 3 & 0.7 \\
Vacancy & 3 & 0.7 \\
Total & 433 & 100.0 \\
\hline
\end{tabular}

Source: Own elaboration (2018). 
The purchase of votes is a phenomenon widely reported in the political history of Brazil (Porto, 1989; Nicolau, 2012) and constitutes one of the facets of typical coronelismo in the interior of the country (Leal, 1975). On the other hand, the change in the regime of ineligibilities promoted by Complementary Law 135/10 (Clean Registry Act) is the result of a wide range of civil society entities, among which include the Movement for Combating Election Corruption and the Association of Brazilian Magistrates (Barbosa, 2010: p. 20). The new legal system was responsible for the removal of thousands of politicians from the electoral contest. This action of the social movements and other members of the civil society in the formulation of laws that increase the power of the cuts is foreseen by the Tate's model and appears like one of the facilitating conditions of the judicialization.

When the reasons for the depositions are observed year after year, some facts deserve to be highlighted. Table 3 below shows the reasons for depositions.

The 2008 elections were those that most provoked voiding/denials of registration by slush funds (Article 30-A of Law 9504/97), vote buying (Article 41-A of Law 9504/97), Ineligibilities of the Complementary Law 64/90 and Itinerant Mayor or Professional Mayor (Article 14, $\$ 5$ of the Federal Constitution).

The legal figure of representation for funding or illicit expenditure of resources for electoral purposes, the so-called slush funds campaign, emerged in the country legal order with the electoral reform idealized by Law 11,300 of 2006, which added Article 30-A to Law of Elections. Therefore, the impact of the new legislation would only be felt in the elections following the promulgation of the law, which in fact can be verified by the empirical evidence.

Table 3. Reasons for depositions per year of regular election.

\begin{tabular}{ccccccc}
\hline & \multicolumn{5}{c}{ Year (regular election) } \\
\hline \multirow{2}{*}{ Reasons } & 2004 & 2008 & 2012 & 2016 & Total \\
\cline { 3 - 6 } & Power Abuse & $12.3 \%$ & $4.0 \%$ & $7.1 \%$ & $9.4 \%$ & $7.4 \%$ \\
& Slush Funds & $0.0 \%$ & $7.4 \%$ & $3.5 \%$ & $1.9 \%$ & $3.9 \%$ \\
Vote Buying & $41.5 \%$ & $43.0 \%$ & $31.9 \%$ & $8.5 \%$ & $31.4 \%$ \\
Sealed Ducts & $32.3 \%$ & $8.7 \%$ & $8.8 \%$ & $8.5 \%$ & $12.2 \%$ \\
Clean Registry Act & $0.0 \%$ & $0.0 \%$ & $31.9 \%$ & $66.0 \%$ & $24.5 \%$ \\
Impeachment & $0.0 \%$ & $0.0 \%$ & $1.8 \%$ & $0.9 \%$ & $0.7 \%$ \\
Formal irregularity & $4.6 \%$ & $2.7 \%$ & $6.2 \%$ & $0.0 \%$ & $3.2 \%$ \\
Ineligibilities & $3.1 \%$ & $28.2 \%$ & $2.7 \%$ & $0.0 \%$ & $10.9 \%$ \\
Nepotism & $1.5 \%$ & $0.0 \%$ & $3.5 \%$ & $1.9 \%$ & $1.6 \%$ \\
Professional Mayor & $4.6 \%$ & $4.7 \%$ & $2.7 \%$ & $1.9 \%$ & $3.5 \%$ \\
Vacancy & $0.0 \%$ & $1.3 \%$ & $0.0 \%$ & $0.9 \%$ & $0.7 \%$ \\
Total & 65 & 149 & 113 & 106 & 433 \\
\hline
\end{tabular}

Source: Own elaboration (2018). 
Although the legal figure of the illicit capture of suffrage, known as vote buying, had already existed since Law 9840/99, it should be noted that its legislation has changed considerably since 2009. Law 12,034/2009 introduced several changes both in the Election Law and in the Law of Political Parties. It had as signatories, leaders of all the parties with representation in the Chamber at the time, as well as the Feminine Workbench.

The first paragraph of Article 41-A of Law 9504/97 was introduced, which makes it unnecessary to explicitly request votes to characterize the illegal conduct of vote buying.

When it is observed that the voicings were based on the vote buying for the 2008 elections, 55 cases, corresponding to $86 \%$ of the total, are found after the amendment of Article 41-A of Law 9504/97. Although it is undeniable that legal changes in the electoral scope are not applicable ex tunc, one can see the influence of the legal context in the formation of the decision-making process by the judges and courts.

The facts suggest that the historical moment was favorable to tightening the rules pertaining to voting, which would allow the judges to act more rigorously. This could also be the reason for the sudden increase in the rejection of application records based on the Law of Ineligibilities (LC 64/90).

As mentioned in the explanation of the methodology, the ineligibilities were divided into two categories in this research: those prior to the edition of Complementary Law 135/10 (Clean Registry Act) were treated as Ineligibilities of LC 64/90; the later ones were classified in the category Clean Registry Act. In this way, the research indicates that the Ineligibilities of LC 64/90 suffered a sudden increase in 2008, like the one occurring with the vote buying.

Consistent with this inference, the ineligibilities arising from the Clean Registry Act appear in 2012 with a higher number of occurrences than those resulting from the previous regime of ineligibility. Apparently, the tightening of the law favored a more incisive position in the Judiciary in the decision.

Finally, the Itinerant Mayor, also known as Professional Mayor, deserves equal prominence, because although in absolute terms the numbers are not expressive, the comparison with the other years highlights the year 2008. The TSE always understood that the mayor reelected in a certain municipality could apply for the same position in another municipality, observing the deadlines for leave office, electoral domicile and party affiliation.

As of the 2008 elections, however, the TSE changed its orientation by judging the Special Electoral Appeal (Respe) 32507, establishing the understanding that Article 14, paragraph 5, of the Federal Constitution prohibits perpetration in the position, and it is not possible to have a subsequent third term, even if in a different municipality.

This understanding was maintained by the STF, which, on August 1, 2012, established the Extraordinary Appeal (RE 637485) by a majority of votes, a stipulation that makes the citizen who has held two consecutive terms in the municipal 
executive, ineligible for the position of mayor even if they are applying for a different municipality.

The intersection of motives by region of the country highlights the Northeast and Southeast regions. While the Northeast is the champion in relation to illicit capture of suffrage, the Southeast is an isolated leader in relation to the ineligibility of the Clean Registry Act. This is shown in Table 4 below.

It does not seem surprising that the Southeast and Northeast regions present the highest frequencies of supplementary elections, respectively 134 and 130 elections, since they are also the regions with the largest number of municipalities; the Northeast has 1794 and the Southeast has 1668. In the period studied, there were supplementary elections in all States of the Federation.

The state with the highest number of occurrences in absolute terms is Minas Gerais, with 63 elections, which corresponds to $14.5 \%$ of the total. However, Minas Gerais with its 853 municipalities is the state with the highest number of this type of federal entity, which means that, in proportional terms, its participation falls to the 18th position in the ranking of supplementary elections.

The ranking was established by comparing the number of elections held in the period studied (number of municipalities multiplied by four) and the supplementary elections. In this way, one can gauge the impact of these extemporaneous elections on the total number of elections held in the period. According to this criterion, the State of Rio Grande do Norte comes first with approximately $4 \%$ of supplementary elections on the total number of elections held from 2004 to 2016 .

Table 4. Reasons for the supplementary elections by region.

\begin{tabular}{|c|c|c|c|c|c|c|}
\hline \multicolumn{7}{|c|}{ Region } \\
\hline Reason & Midwest & Northeast & North & Southeast & South & Total \\
\hline Power Abuse & $8.7 \%$ & $10.0 \%$ & $2.7 \%$ & $6.7 \%$ & $5.8 \%$ & $7.4 \%$ \\
\hline Slush Funds & $2.2 \%$ & $1.5 \%$ & $2.7 \%$ & $4.5 \%$ & $8.1 \%$ & $3.9 \%$ \\
\hline Vote Buying & $37.0 \%$ & $41.5 \%$ & $24.3 \%$ & $23.1 \%$ & $29.1 \%$ & $31.4 \%$ \\
\hline Sealed Ducts & $6.5 \%$ & $10.0 \%$ & $13.5 \%$ & $15.7 \%$ & $12.8 \%$ & $12.2 \%$ \\
\hline Clean Registry Act & $30.4 \%$ & $7.7 \%$ & $29.7 \%$ & $32.8 \%$ & $31.4 \%$ & $24.5 \%$ \\
\hline Impeachment & $0.0 \%$ & $0.0 \%$ & $0.0 \%$ & $1.5 \%$ & $1.2 \%$ & $0.7 \%$ \\
\hline Formal irregularity & $2.2 \%$ & $6.2 \%$ & $8.1 \%$ & $0.7 \%$ & $1.2 \%$ & $3.2 \%$ \\
\hline Ineligibilities & $10.9 \%$ & $13.8 \%$ & $13.5 \%$ & $9.7 \%$ & $7.0 \%$ & $10.9 \%$ \\
\hline Nepotism & $0.0 \%$ & $0.8 \%$ & $2.7 \%$ & $2.2 \%$ & $2.3 \%$ & $1.6 \%$ \\
\hline Professional Mayor & $0.0 \%$ & $8.5 \%$ & $2.7 \%$ & $1.5 \%$ & $1.2 \%$ & $3.5 \%$ \\
\hline Vacancy & $2.2 \%$ & $0.0 \%$ & $0.0 \%$ & $1.5 \%$ & $0.0 \%$ & $0.7 \%$ \\
\hline Total & 46 & 130 & 37 & 134 & 86 & 433 \\
\hline
\end{tabular}

Source: Own elaboration (2018). 
As for the size of the municipality, it can be said that supplementary elections constitute a phenomenon typical of small towns. The Brazilian Institute of Geography and Statistics (IBGE) classifies the municipalities in a scale of four segments: Small Porte I, for municipalities with up to 20,000 inhabitants; Small Porte II, for municipalities from 20,001 to 50,000; Medium Porte, for municipalities between 50,001 and 100,000; Large Porte for those with population between 100,001 and 900,000. Municipalities with more than 900,000 inhabitants are metropolises. According to this classification, just over $90 \%$ of the supplementary elections occurred in municipalities with less than 50,000 inhabitants.

The data corroborate the findings of Garcia (2016: p. 61), for whom, proportionally, there was a higher incidence of these disputes among the small municipalities of the country. The following Table 5 shows the reasons for the additional municipal elections by size.

In cities with less than 20,000 inhabitants, the cases of vote buying predominate. In cities with 20,001 to 50,000 inhabitants, the percentage of supplementary elections motivated by vote buying is equal to those resulting from the Law of Clean Registry Act. It can be affirmed, then, that as the size of the municipality increases, the axis of the motives of the vote buying moves towards the ineligibility of the Clean Registry Act. In medium and large municipalities, the higher percentages of supplementary elections are derived from the Clean Registry Act.

It is also noted that supplementary elections constitute a multiparty phenomenon. In all, 28 parties had mayors deposed. In relation to the ideological alignment, a predominance of right-center or right-wing parties is observed, which account for approximately $80 \%$ of the cases.

Table 5. Reasons for the supplementary elections by municipality size (IBGE).

\begin{tabular}{cccccc}
\hline Reasons & Large Porte & Medium Porte & Small Porte II & Small Porte I & Total \\
\hline Power Abuse & $4.3 \%$ & $16.7 \%$ & $8.5 \%$ & $6.80 \%$ & $7.4 \%$ \\
Slush Funds & $8.7 \%$ & $0.0 \%$ & $3.7 \%$ & $3.90 \%$ & $3.9 \%$ \\
Vote Buying & $4.3 \%$ & $16.7 \%$ & $24.4 \%$ & $36.10 \%$ & $31.4 \%$ \\
Sealed Ducts & $17.4 \%$ & $16.7 \%$ & $12.2 \%$ & $11.60 \%$ & $12.2 \%$ \\
Clean Registry Act & $47.8 \%$ & $44.4 \%$ & $24.4 \%$ & $21.60 \%$ & $24.5 \%$ \\
Impeachment & $0.0 \%$ & $0.0 \%$ & $0.0 \%$ & $1.00 \%$ & $0.7 \%$ \\
Formal irregularity & $4.3 \%$ & $0.0 \%$ & $3.7 \%$ & $3.20 \%$ & $3.2 \%$ \\
Ineligibilities & $4.3 \%$ & $0.0 \%$ & $14.6 \%$ & $11.00 \%$ & $10.9 \%$ \\
Nepotism & $0.0 \%$ & $0.0 \%$ & $2.4 \%$ & $1.60 \%$ & $1.6 \%$ \\
Professional Mayor & $4.3 \%$ & $5.6 \%$ & $6.1 \%$ & $2.60 \%$ & $3.5 \%$ \\
Vacancy & $4.3 \%$ & $0.0 \%$ & $0.0 \%$ & $0.60 \%$ & $0.7 \%$ \\
Total & 23 & 18 & 82 & 310 & 433 \\
\hline
\end{tabular}

Source: Own elaboration (2018). 
The party with the largest number of depositions is the MDB, followed by the PSDB. Coincidentally, these are the parties that elected the largest number of mayors in the period ${ }^{6}$. There are, therefore, no great surprises, and there is correlation between the number of mayors elected by the party and the number of deposed mayors. That is, on average, the parties that most elect mayors are also the parties that have more mayors deposed.

It is also noted that the vote buying and the ineligibilities resulting from the Clean Registry Act constitute the main reasons for depositions of mayors in most parties. In the MDB, for example, the vote buying is responsible for $32 \%$ and the ineligibilities are responsible for $24 \%$. The PSDB numbers are $32 \%$ and $25 \%$, respectively.

Although the Brazilian academic production, in a largely majority way, has always been dedicated to the study of the courts when it intends to deal with the judicialization of the electoral competition (Marchetti, 2008, 2013; Zauli, 2011; Steibel, 2007; Bitencourt, 2013; Marchetti \& Cortez, 2015; Pozzobon, 2009; Costa, 2013; Junior, 2014; Lima \& Beçak, 2016; Oliveira et al., 2018), we observe that the phenomenon of judicialization is not limited to the higher courts.

When the origin of the deposition decisions is observed, there is a clear predominance of the singular judge or first instance judges in the deposition processes. The first instance is therefore responsible for approximately $73 \%$ of all decisions leading to further elections.

In fact, the role of the first instance of the judiciary in the electoral sphere cannot be neglected. The Justice in Numbers report (CNJ, 2018) points out that the external recess index of the Electoral Court in Brazil in 2017 was 4.4\%. That is, only $4 \%$ of the sentences handed down by electoral judges were appealed to the High Courts, which leads to the inference that a minimum percentage of first instance judicial decisions in the Electoral Court are subject to change.

When one observes the historical series, it is verified that even in election years the index does not exceed $20 \%$. This is a good indication of the power of electoral judges and how their interference from the electoral game can effectively define the direction of competition.

However, except in cases of explicit judicial activism, the judicialization is a phenomenon that needs actors that lead to the judiciary to deal with. That is, the parties must bring the discussion that they wish to see judicialized to the knowledge of the judiciary. When it comes to the judicialization of electoral competition, the parties may be the Public Prosecutor's Office, candidates and coalitions, representatives of political parties, citizens and even judicial bodies, since the Electoral Court has the sui generis characteristic of performing administrative functions in parallel to the judges (Gomes, 2017: p. 2409).

Approximately $58 \%$ of the supplementary elections were motivated solely by opposition political parties. That is, in 250 elections, the opposition was solely responsible for investigating, collecting evidence and provoking the judiciary to ${ }^{6}$ The MDB elected in 2004, 2008, 2012 and 2016 the following number of mayors: 1060, 1202, 1047 and 1021. The PSDB comes in second place: 870, 791, 801 and 695. 
carry out the deposition of the originally elected mayor. It should be remembered that all actions that culminate in depositions analyzed in this work are not criminal in nature and absent the plaintiffs' action, the political situation of the municipalities would not change. In approximately $22 \%$ of cases, the opposition acted incisively together with the Public Prosecutor. The Public Prosecutor acted alone in only $18 \%$ of the cases.

The scenarios in which opposition parties acted as authors or coauthors of the actions cover $80 \%$ of the supplementary elections, which suggests that the parties are the main ones responsible for the judicialization of the elections that ended invalidated, either by the cassation, or by the rejection of the registration of the plaque winner. In a little more than $2 \%$ of the supplementary elections, the judiciary ordered the dismissal of the ex officio registration, in the exercise of its administrative attribution.

The case of the municipality of Água Preta/PE, in which the candidate Armando Almeida Souto of the PDT had its registration contested by allies for irregularities in the party convention, deserves record. The candidate was re-elected in the subsequent supplementary election. This was the only case in which the cassation took place on the initiative of a party allied with the elected candidate.

A natural unfolding of our working hypothesis about the high judicialization of municipal electoral competition, seen through the supplementary elections, would be the realization that prosecution is a usual strategy of political contenders. However, the question remains about the validity of this strategy.

The frequency of supplementary elections provoked by opposition groups confirms the first assertion and, in fact, judicialization seems to be an additional strategy in municipal electoral competition. After all, if a strategy does not work, it tends to be abandoned, or at least underutilized.

This makes relevant the intersection between the authorship of the actions and the political alignment of the mayors elected in the supplementary elections in relation to the deposed mayors. That is, the objective is to know if, after the accomplishment of the supplementary election, the political coalition in power was renewed.

When we observe the results of all the supplementary elections surveyed, we can see an apparent balance, with opposition political parties electing 216 mayors and the political coalition of the previous mayor choosing 217. In other words, opposition political parties manage to take power in approximately $50 \%$ of the cases. The figures are somewhat lower than those recorded by Garcia (2014: p. 155), who pointed out that the group winning the ordinary election would continue in the municipal government in $53.3 \%$ of the cases. However, the database of that work computed only 113 supplementary elections, referring to 112 municipalities, regarding the regular elections of 2012.

In virtually all scenarios, mayors elected in supplementary elections are mostly allies of the previous mayor. However, when the opposition is the author of the lawsuit responsible for the new election, the results are reversed, and the opposi- 
tion mayors win in most cases. When opposition groups act alone in deposition actions, approximately $63 \%$ of the supplementary elections that they dispute are due. Apparently, judicializing electoral competition brings benefits to opposition political parties and allows for increased chances of victory in a sort of court-ordered "third round."

\section{Findings with Analysis}

The theme of the municipal supplementary elections is still little explored in the Brazilian academy. The few existing works, such as Zalamena (2013), Coelho (2014), Garcia (2016) and Crespo (2017) deal with the theme in a limited way in space or time.

The data collected indicate that the use of actions aimed at the deposition of mayors has become an additional strategy in electoral competition. After all, approximately $58 \%$ of the actions were moved solely by opposition parties. When the cases in which the opposition acted jointly with the Public Prosecutor's office are added to the figures, the figure reaches a staggering $80 \%$ of the cases.

There is also a balance sheet, with opposition political groups and allies of the previous mayor each winning approximately $50 \%$ of the supplementary elections analyzed. However, this is only an apparent balance, because on average, defeated political groups that judicialize the electoral process and succeed in invalidating the regular elections, obtain the power in half of the supplementary elections that they contend for. That is, the holding of new elections allowed them to reverse adverse results.

The numbers are even more significant when opposition groups act alone in deposition actions. In these cases, approximately $63 \%$ of the supplementary elections that they dispute are due. As Coelho (2014: p. 141) points out, "political actors note that they can obtain electoral gains through legal devices, and do not hesitate to use them".

This discussion is not only of a theoretical nature, because the consequences of the judicialization are not always visible immediately. In the electoral context, the well-known slowness of the judicial apparatus, which is often recognized as necessary for the reliability of decisions, can produce the opposite effect and discredit justice.

It is hoped, therefore, that new work on the subject will emerge and that it can be included in the public debate, since elections constitute the guarantor of the legitimacy of democratic governments and no better alternative has been found in the Modern Constitutional State.

\section{Conflicts of Interest}

The author declares no conflicts of interest regarding the publication of this paper.

\section{References}

Arantes, R. B. (2005). Constitutionalism, the Expansion of Justice and the Judicialization of Politics in Brazil. In R. Sieder, L. Schjolden, \& A. Angell (Eds.), The Judicialization 
of Politics in Latin America (pp. 231-262). Studies of the Americas, New York: Palgrave Macmillan. https://doi.org/10.1007/978-1-137-10887-6_10

Barbosa, D. D. L. (2010). A magistratura e a Lei da Ficha Limpa. In M. J. Reis et al. (Eds.), Ficha Limpa (pp. 19-21). São Paulo: Edipro.

Barboza, E. M. de Q., \& Kozicki, K. (2012). Judicialização da política e controle judicial de políticas públicas. Revista Direito GV, 8, 59-85.

https://doi.org/10.1590/S1808-24322012000100003

http://bibliotecadigital.fgv.br/ojs/index.php/revdireitogv/article/view/23970/22728

Bitencourt, J. G. G. (2013). Entre as urnas e as togas: Justiça eleitoral e competição política no Pará (1982-1986). Paraná Eleitoral, 2, 261-282.

Canela Júnior, O. (2012). O controle jurisdicional do processo político no Brasil. Paraná Eleitoral, 1, 183-193.

Carvalho, E. R. (2004). Em busca da judicialização da política no Brasil: Apontamentos para uma nova abordagem. The Revista de Sociologia e Política, Curitiba, 23, 127-139. https://doi.org/10.1590/S0104-44782004000200011 http://www.scielo.br/scielo.php?script=sci_arttext\&pid=S0104-44782004000200011\&ln $\mathrm{g}=\mathrm{en} \& \mathrm{nrm}=\mathrm{iso}$

Castro, M. F. (1993). Política e Economia no Judiciário: As Ações Diretas de Inconstitucionalidade dos Partidos Políticos. Brasília: Dissertação apresentada ao Departamento de Ciência Política do Instituto de Ciência Política e Relações Internacionais da Universidade de Brasília para obtenção do título de Mestre em Ciência Política.

Coelho, M. C. (2014). A democracia na encruzilhada: Reflexões acerca da legitimidade democrática da justiça eleitoral para a cassação de mandatos eletivos no Brasil. Dissertação (Mestrado em Direito), São Leopoldo: Universidade do Vale do Rio dos Sinos Unisinos. http://www.repositorio.jesuita.org.br/handle/UNISINOS/3802

Conselho Nacional de Justiça (CNJ) (2018). Justiça em Números 2017. Brasília: CNJ.

Costa, T. C. (2013). Justiça Eleitoral e sua competência normativa. Parana Eleitoral, 2, 99-114.

Crespo, R. A. (2017). Eleições Suplementares no Brasil: Os Casos Decorrentes das Anulações dos Pleitos de 2012. Dissertação de Mestrado em Sociologia Política. Universidade Estadual do Norte Fluminense Darcy Ribeiro.

Crespo, R., \& Peixoto, V. (2018). Eleições Suplementares nos Municípios Brasileiros: Os Casos nas Eleições De 2012. CSOnline-Revista Eletrônica de Ciências Sociais, No. 27, 170-185. https://doi.org/10.34019/1981-2140.2018.17441

Garcia, B. S. (2016). Eleições Suplementares para Prefeito (2013-2015): Do perfil socioeconômico dos municípios ao comportamento eleitoral e partidário. Dissertação (Mestrado em Ciência Política), Pelotas: Universidade Federal de Pelotas.

https://wp.ufpel.edu.br/ppgcienciapolitica/files/2016/07/Bruno-Souza-Garcia-2016.pdf

Gomes, J. J. (2017). Direito Eleitoral (13th ed.). São Paulo: Atlas. (Edição Digital)

Hamlin, R., Kawar, L., \& Sala, G. (2015). The Judicialization of Politics: An Essentially Contested Concept. In The Five College Faculty Seminar in Legal Studies. Amherst, MA, 15 October 2015.

https://www.academia.edu/35542282/The_Judicialization_of_Politics_An_Essentially_ Contested_Concept

Huntington, S. P. (1994). A terceira onda: A democratização no final do século XX. Ática.

Junior, A. T. N. (2014). Ativismo judicial no Brasil: O caso da fidelidade partidária. Revista de Informação Legislativa, 51, 97-128. 
Kerche, F. (1999). Judiciário e democracia no Brasil. Novos Estudos, Rio de Janeiro, 54, 27-41.

Kinzo, M. D. G. (2004). Partidos, eleições e democracia no Brasil pós-1985. Revista Brasileira de ciências sociais, 19, 23-40. https://doi.org/10.1590/S0102-69092004000100002

Kinzo, M. D. G. (2007). Partidos, deputados estaduais e a dimensão ideológica. In M. D. G. Kinzo, \& M. do S. S. Braga (Eds.), Eleitores e representação partidária no Brasil (pp. 139-158). São Paulo: Associação Editorial Humanitas.

Kmiec, K. D. (2004). The Origin and Current Meanings of Judicial Activism. California Law Review, 92, 1441. https://doi.org/10.2307/3481421

Koerner, A., Inatomi, C. C., \& Baratto, M. (2011). Sobre o judiciário e a judicialização. Nuevos Paradigmas de las Ciencias Sociales Latinoamericanas, 4, 17-52.

Leal, V. N. (1975). Coronelismo, enxada e voto. São Paulo: Editora Alfa-ômega.

Lima, J. N., \& Beçak, R. (2016). Judicialização da "Mega Política": Um Estudo de Caso a Partir do Alcance Normativo da Consulta Eleitoral do Tribunal Superior Eleitoral. Revista Brasileira de Teoria Constitucional, 2, 1130-1146. https://doi.org/10.26668/IndexLawJournals/2525-961X/2016.v2i2.1540

Marchetti, V. (2004). O Controle Constitucional da Atividade Legislativa do Executivo: Brasil e Argentina comparados. Revista Teoria \& Sociedade, Belo Horizonte, 12, 56-79.

Marchetti, V. (2008). Governança Eleitoral: O modelo brasileiro de Justiça Eleitoral. DADOS Revista de Ciências Sociais, 51, 865-893. https://doi.org/10.1590/S0011-52582008000400003

Marchetti, V. (2013). Justiça e competição eleitoral. Santo André: Universidade Federal do ABC.

Marchetti, V., \& Cortez, R. (2015). A judicialização da competição política: O TSE e as coligações eleitorais. Opinião Pública, Campinas, SP, 15, 422-450.

https://doi.org/10.1590/S0104-62762009000200006

https://periodicos.sbu.unicamp.br/ojs/index.php/op/article/view/8641337/8847

Moura, R. S. (2018). Eleições 2.0: O Uso das Redes Sociais Digitais durante as Eleições Suplementares ao Governo do Estado do Amazonas. Dissertação de Mestrado em Psicologia, Manaus: Universidade Federal do Amazonas.

Mozaffar, S., \& Schedler, A. (2002). The Comparative Study of Electoral Governance-Introduction. International Political Science Review, 23, 5-27. https://doi.org/10.1177/0192512102023001001

Nicolau, J. (2012). Eleições no Brasil. Do Império aos dias atuais. Rio de Janeiro: Zahar.

Oliveira, G. P. et al. (2018). O protagonismo do Tribunal Superior Eleitoral e o seu impacto na relação de accountability entre Legislativo e Judiciário. Dissertação (Mestrado em Ciência Política), Universidade Federal São Carlos. https://repositorio.ufscar.br/bitstream/handle/ufscar/10398/OLIVEIRA_Geovane_2018 .pdf? sequence $=6 \&$ isAllowed $=y$

Oliveira, V. E. (2005). Judiciário e privatizações no Brasil: Existe uma judicialização da política? Dados Revista de Ciências Sociais, 48, 559-587. https://doi.org/10.1590/S0011-52582005000300004

Paranhos, R., Nascimento, W., Dias, A. C. A., Carvalho, R. B., \& Neto, J. M. W. G. (2014). $O$ que é que a Judicialização Eleitoral tem? Cadernos Adenauer XV, N. 1. Rio de Janeiro: Fundação Konrad Adenauer.

Pogrebinschi, T. (2012). Judicialização ou representação? Política, direito e democracia 
no Brasil. Rio de Janeiro: Elsevier. https://doi.org/10.1016/B978-85-352-5150-0.50014-7

Porto, W. C. (1989). O voto no Brasil. Da Colônia à Quinta República (Vol. 1). Brasília: Gráfica do Senado Federal.

Pozzobon, P. H. (2009). O Supremo Tribunal Federal e a Judicialização da Política no Brasil. Revista da Faculdade de Direito UniRitter, 10, 97-118.

Ribeiro, F. (1990). Pressupostos constitucionais do Direito Eleitoral. No caminho da sociedade participativa. Porto Alegre: Sergio Antonio Fabris Editor.

Ribeiro, H. (2001). Justiça e Democracia. Porto Alegre: Síntese.

Shirado, N. (2008). A titularidade do mandato eletivo nos sistemas majoritário e proporcional e seus reflexos sobre a infidelidade partidária na visão dos tribunais brasileiros. TRE-PR Revista Paraná Eleitoral, 67, 1-24.

Shirado, N. (2009). Ética da legalidade \& judicialização da política no estudo da vida pregressa e da moralidade para o exercício de mandato eletivo. TRE-PR Revista Paraná Eleitoral, 71, 1-19.

Silva, C. A. (2004). O processo civil como estratégia de poder: Reflexo da judicialização da política no Brasil. Rio de Janeiro: Renovar.

Steibel, F. (2007). Direito de resposta e judicialização da política na propaganda política brasileira. Rastros-Revista do Núcleo de Estudos de Comunicação, 8, 8-62.

Streck, L. L. (2017). Verdade e consenso. Constituição, hermenêutica e teorias discursivas (6th ed.). São Paulo: Saraiva.

Tassinari, C. (2013). Jurisdição e ativismo judicial: Limites da atuação do judiciário. Porto Alegre: Livraria do Advogado.

Tate, C. N. (1995). Why the Expansion of Judicial Power? In T. Vallinder, \& C. N. Tate (Eds.), The Global Expansion of Judicial Power: The Judicialization of Politics (pp. 27-39). New York: New York University.

Taylor, M. M. (2006). Veto and Voice in the Courts: Policy Implications of Institutional Design in the Brazilian Judiciary. Comparative Politics, 38, 337-355. https://doi.org/10.2307/20434001

Taylor, M. M. (2007). O judiciário e as políticas públicas no Brasil. DADOS-Revista de ciências sociais, 50, 229-257. https://doi.org/10.1590/S0011-52582007000200001

Teixeira, A. (1997). A judicialização da política no Brasil (1990-1996). Brasília: Dissertação apresentada ao Departamento de Ciência Política do Instituto de Ciência Política e Relações Internacionais da Universidade de Brasília para obtenção do título de Mestre em Ciência Política.

Vallinder, T. (1995). When the Courts Go Marching. In T. Vallinder, \& C. N. Tate (Eds.), The Global Expansion of Judicial Power: The Judicialization of Politics (pp. 13-26). New York: New York University.

Verbicaro, L. P. (2008). Um estudo sobre as condições facilitadoras da judicialização da política no Brasil. Revista Direito GV, 4, 389-406.

https://doi.org/10.1590/S1808-24322008000200003

http://bibliotecadigital.fgv.br/ojs/index.php/revdireitogv/article/view/35157/33962

Vianna, L. W., Carvalho, M. A. R., Melo, M. P. C., \& Burgos, M. B. (1999). A judicialização da política e das relações sociais no Brasil. Rio de Janeiro: Editora Revan.

Zalamena, J. C. M. (2013). Judicialização, competição política local e eleições municipais no Rio Grande do Sul. 134 f. Dissertação (Mestrado em Ciência Política), Porto Alegre: Universidade Federal do Rio Grande do Sul. http://hdl.handle.net/10183/104872

Zauli, E. M. (2011). Justiça eleitoral e judicialização das eleições no Brasil. Revista Brasileira de Estudos Políticos, 102, 255-290. 